\title{
Peanut Hull and Arjuna Tree Bark Powders as Potential Functional Ingredients in Development of Low-Fat, High-Fibre Pork Patties
}

\author{
Pavan Kumar $^{1 *}$, Simranjeet Kaur ${ }^{1}$, Mayank Goswami ${ }^{1}$, Nitin Mehta ${ }^{1}$, Mehak Jandyal ${ }^{1}$, \\ Tanuj Tanwar ${ }^{1}$ and Ajeet Singh ${ }^{2}$ \\ ${ }^{1}$ Department of Livestock Products Technology, College of Veterinary Science, Guru Angad Dev Veterinary and Animal Sciences \\ University, Ludhiana, Punjab, INDIA \\ ${ }^{2}$ Department of Harvest and Post-Harvest Technology, College of Fisheries, Guru Angad Dev Veterinary and Animal Sciences \\ University, Ludhiana, Punjab, INDIA \\ *Corresponding author: P Kumar; E-mail:vetpavan@gmail.com
}

Received: 01 April, 2021

Revised: 02 May, 2021

Accepted: 06 May, 2021

\begin{abstract}
The present study was envisaged to develop low-fat, high-fibre pork patties by incorporating optimum combinations of peanut hull powder (PHP) and arjuna tree bark powder (ATBP) in the basic formulation replacing lean meat. Five various combinations were prepared by using two different levels of peanut hull powder (PHP) viz. $0.5 \%$ and $1.0 \%$ and arjuna tree bark powder (ATBP) viz. $1.0 \%$ and $1.5 \%$ by using two-by-two factorial design viz. control (without PHP and ATBP), T1 (0.5\% PHP and $1.0 \%$ ATBP), T2 (0.5\% PHP and 1.5\% ATBP), T3 (1.0\% PHP and 1.0\% ATBP) and T4 (1.0\% PHP and $1.5 \%$ ATBP). The developed products were evaluated for various physico-chemical, proximate, instrumental colour, texture profile and sensory analysis. With increasing levels of PHP and ATBP in the developed products, mean fat and protein values exhibited decreasing trend whereas ash content showed increasing trend. Control exhibited significantly $(\mathrm{P}<0.05)$ lower crude fibre content as compared to treated patties. The lightness $\left(L^{*}\right)$ value of T2 and T3 was recorded comparable and significantly $(\mathrm{P}<0.05)$ higher than T4. The mean overall acceptability score of $\mathrm{T} 2$ was comparable to $\mathrm{T} 1$. The overall acceptability of control was recorded significantly $(\mathrm{P}<0.05)$ higher than $\mathrm{T} 1$ and $\mathrm{T} 2$. Thus low-fat, high-fibre, functional pork patties with good organoleptic quality can be prepared by incorporation of $0.5 \%$ peanut hull powder and $1.5 \%$ arjuna tree bark powder.
\end{abstract}

\section{HIGHLIGHTS}

(0 Peanut hull and arjuna tree bark powders are rich source of dietary fibre, minerals and flavonoids.

( Good quality low-fat, high-fibre, functional pork patties can be prepared by incorporation of $0.5 \%$ peanut hull powder and $1.5 \%$ arjuna tree bark powder.

Keywords: Peanut hull, arjuna tree bark, low-fat, high-fibre, pork patties

Processing of peanut resulted in production of huge quantity of several byproducts possessing valuable nutrients. These peanut industry byproducts such as peanut hull, skin, meal, etc. are considered as agricultural waste and potential environmental hazard. Among peanut byproducts, peanut hull is largely underutilized and disposed inefficiently by incineration, landfills as absorbent in textile industry and for removing heavy metals, etc. It constitutes about 20-30 $\%$ of total weight of peanut and thus based on total global production of peanut, about 10 million metric tonnes of peanut hulls are estimated to be produced every year (Zhao et al., 2012).

Peanut hull powder is rich in dietary fibres $(60-62 \%$ in mature peanut hull) and other bioactive ingredients having nutritional importance. Peanut hull contains about $86.16 \%$

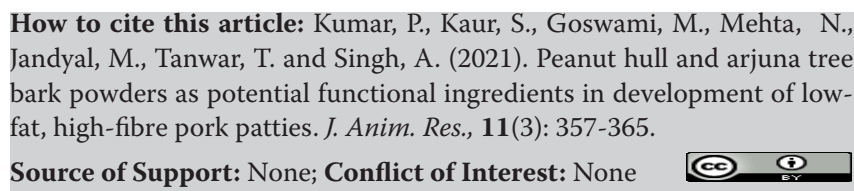
Jandyal, M., Tanwar, T. and Singh, A. (2021). Peanut hull and arjuna tree bark powders as potential functional ingredients in development of low(क) 9 
NDF (neutral detergent fibre) and 73.98\% ADF (acid detergent fibre) comprising 34.56\% lignin and 39.42\% cellulose (Zhao et al., 2012). The lignin content of peanut hull was reported higher than most vegetables and cereals and its regular consumption had been associated with lowering cholesterol consumption by binding bile acid with lignin. Yu et al. (2011) reported 2.68\% yield of soluble dietary fibres (SDF) from peanut hull by microwave assisted extraction along with medicinal compounds such as xylose, saponn and $\beta$-sitosterol. Peanut hull is a rich source of flavonoids having antioxidative properties with luteolin $(0.25-1.12 \mathrm{mg} / \mathrm{g}$ ) as major flavonoid (Akgul and Tozluoglu, 2008). Yu et al. (2011) reported very strong hydroxyl free radical scavengering activity of peanut hull powder with IC 50 value of $0.78 \mathrm{mg} / \mathrm{mL}$. The superoxide anion free radicals and 2, 2-diphenyl-1-picrylhydrazyl (DPPH) IC50 value were reported $6.66 \mathrm{mg} / \mathrm{mL}$ and 5.12 $\mathrm{mg} / \mathrm{mL}$. Thus peanut hull flour could be a potential source of dietary fibre and natural antioxidants in food processing.

Arjuna or Arjun tree (Terminalia arjuna) is an evergreen deciduous plant of Combretaceae family widely distributed across Indian Subcontinent. All its parts such as stem, roots, leaves, and fruits are rich in various bioactive compounds such as flavonoids, triterpenoids, glycosides, sitosterol, polyphenols, tannins etc and minerals. Out of all arjuna tree parts, bark had highest concentration of flavonoids such as arjunolone, flavones, bicalein, quercetin, kempferol and pelorgonidin. Arjuna tree bark extract has been reported to possess strong antioxidant effect in food matrix and enhanced storage stability of pork products (Birla et al., 2019), buffalo male calves meat rolls (Bishnoi et al., 2017), etc. The arjuna tree bark and fruits has been reported to possess several medicinal activities such as cardioprotective and stimulants, hepatoprotective, antidiarrhoea, etc. and thus widely used as main ingredient in several ethno-medicinal preparations. Although its use in traditional system of medicine was widely explored but its use as potential natural preservative still remain unexplored.

Meat and meat products are inherently low in dietary fibre and are very prone of spoilage due to oxidation of meat lipids and proteins as well as microbial proliferation due to presence of unsaturated fatty acids, high moisture and nutrient density (Kumar et al., 2013; Singh et al., $2014 a, b)$. Consumption of diets low in dietary fibre is associated with higher prevalence of obesity, colon cancer, cardiovascular and other chronic metabolic and lifestyle diseases (WHO/FAO, 2003). Various plant powders explored as source of dietary fibre in development of meat products also improve textural and sensorial properties of meat products (Kumar et al., 2018a). There is increasing trend for green consumerism as consumer prefers to eat food without added synthetic preservatives due to potential harmful effect of these compounds on human health (Kumar et al., 2018 a, b; Kantale et al., 2019). The use of peanut hull and arjuna tree bark powders could be potential ingredients to form functional meat products due to presence of polyphenolic compounds, source of dietary fibre and essential minerals. Further this will open an arena for development of agro-food industry and ensure profitable returns to the stakeholders.

Thus, the present study has been undertaken to prepare low-fat, high-fibre functional pork patties by incorporating peanut hull and arjuna tree bark powders and assessing quality thereof.

\section{MATERIALS AND METHODS}

\section{Preparation of peanut hull and arjuna tree bark powders}

Organic peanuts were purchased from local market, Ludhiana, Punjab, India. Arjuna tree bark was scrapped with sharp knife from mature arjuna trees grown up in the premise of Directorate of Livestock Farm, GADVASU, Ludhiana. These were brought to the laboratory, washed with clean water and sun dried. The peanuts was hand shelled to obtain hull. The hull and bark were dried in vacuum oven (Promarks Vac Co Ltd, Taiwan) at $60^{\circ} \mathrm{C}$ till constant weight. The dried hull and bark were ground by mixer-grinder and sieved through stainless steel sieve of 50-60 mesh size to get fine powder. The dried peanut hull and arjuna tree bark powders were packaged in plastic jar and stored under refrigeration till use.

\section{Preparation of the pork patties}

Lean pork was obtained by scientifically slaughter of 3 castrated Large White Yorkshire pigs (Age- 9 months, weighing 80-90 kg) in the departmental slaughter house by following standard protocol. The carcass was chilled, visible fascia and connective tissue were separated and 
manually deboned to get deboned meat. The deboned meat was packaged in 100 gauge low density polyethylene (LDPE) packages and stored at $-18 \pm 2^{\circ} \mathrm{C}$ till use. Before use, frozen meat was thawed (kept overnight under refrigeration temperature $4 \pm 1^{\circ} \mathrm{C}$ ), cut into small chunks and minced twice in meat mincer (MADO Eskimo Mew 714, Spain).

Based on several preliminary trials, two different levels of peanut hull powder (PHP) viz. $0.5 \%$ and $1.0 \%$ and arjuna tree bark powder (ATBP) viz. $1.0 \%$ and $1.5 \%$ were selected. Five various combinations were prepared by using two-by-two factorial design as-

Table 1: Two-by-two factorial design

\begin{tabular}{lccc}
\hline & & \multicolumn{2}{c}{$\begin{array}{c}\text { Arjuna tree bark } \\
\text { powder (ATBP) }\end{array}$} \\
\hline & & $1.0 \%(\mathrm{C})$ & $1.5 \%(\mathrm{D})$ \\
\cline { 2 - 4 } Peanut hull powder (PHP) & $0.5 \%(\mathrm{~A})$ & $\mathrm{T} 1(\mathrm{AC})$ & $\mathrm{T} 2(\mathrm{AD})$ \\
\cline { 2 - 4 } & $1.0 \%(\mathrm{~B})$ & $\mathrm{T} 3(\mathrm{BC})$ & $\mathrm{T} 4(\mathrm{BD})$ \\
\hline Control (C): without PH and ATBP & &
\end{tabular}

Five groups of pork emulsions viz. control (C) and treatments T1, T2, T3 and T4 were prepared by replacing lean meat in the formulation. The minced pork with salt, nitrite and phosphates was chopped in a bowl chopper (Model: TC11, Scharfen, Germany) for 50 seconds followed by addition of ice flakes and further chopping for 80 seconds. Ground pork fat was slowly added and further chopping was done for 120-130 seconds. The remaining ingredients such as spice mix, condiments, whole egg liquid and refined wheat flour were added and chopping for 60 seconds (Table 2). The temperature of emulsion was recorded $11-14^{\circ} \mathrm{C}$.

Table 2: Formulations of low-fat, high-fibre pork patties

\begin{tabular}{llllll}
\hline Ingredients (\%) & Control (C) & T1 & T2 & T3 & T4 \\
\hline Minced Pork & 72.7 & 71.2 & 70.7 & 70.7 & 70.2 \\
PHP & - & 0.5 & 0.5 & 1.0 & 1.0 \\
ATBP & - & 1.0 & 1.5 & 1.0 & 1.5 \\
Fat & 5.0 & 5.0 & 5.0 & 5.0 & 5.0 \\
Water & 10.0 & 10.0 & 10.0 & 10.0 & 10.0 \\
Egg liquid & 2.5 & 2.5 & 2.5 & 2.5 & 2.5 \\
Salt & 1.5 & 1.5 & 1.5 & 1.5 & 1.5 \\
Polyphosphates & 0.3 & 0.3 & 0.3 & 0.3 & 0.3
\end{tabular}

\begin{tabular}{llllll} 
Condiments & 3.0 & 3.0 & 3.0 & 3.0 & 3.0 \\
Spices & 2.0 & 2.0 & 2.0 & 2.0 & 2.0 \\
Refined wheat flour & 3.0 & 3.0 & 3.0 & 3.0 & 3.0 \\
Sodium nitrite & 0.012 & 0.012 & 0.012 & 0.012 & 0.012 \\
\hline
\end{tabular}

*PHP- peanut hull powder, ATBP- arjuna tree bark powder, T1 (0.5\% PHP and $1.0 \%$ ATBP), T2 (0.5\% PHP and $1.5 \%$ ATBP),T3 (1.0\% PHP and $1.0 \%$ ATBP) and T4 (1.0\% PHP and $1.5 \%$ ATBP).

The emulsion was properly filled in moulds $(78 \times 21 \mathrm{~mm})$ without any air gaps and put for cooking in pre-heated hot air oven at $180 \pm 1^{\circ} \mathrm{C}$ for 20 min with regular turning after $10 \mathrm{~min}$ for uniform heating and colour development. The Cooked patties were cooled to room temperature and evaluated for various quality evaluations.

\section{Physico-chemical parameters}

Moisture (oven drying at $105^{\circ} \mathrm{C}$ to a constant weight), protein (kjeldahl distillation, $\mathrm{N} \times 6.25$ ), fat (soxhlet method by using petroleum ether as solvent), crude fibre and ash (muffle furnace by putting samples in quartz crucibles in muffle furnace for $16 \mathrm{~h}$ and gradually increasing temperature from $\left.150^{\circ} \mathrm{C}-600^{\circ} \mathrm{C}\right)$; of pork patties were determined by per AOAC (2006). The total carbohydrate content of pork patties was calculated (carbohydrate $=$ 100-moisture + protien + fat + ash). Total calories content were calculated by using at water values for protein (4.02 $\mathrm{kcal} / \mathrm{g})$, carbohydrate $(4 \mathrm{kcal} / \mathrm{g})$ and fat $(9 \mathrm{kcal} / \mathrm{g})$.

Cooking yield was determined by taking into account the difference in the product weight before and after cooking.

Cooking yield $(\%)=[$ Weight of uncooked pork patties $/$ Weight of cooked pork patties $] \times 100$

Various dimensional parameters such as diameter shrinkage (\%) and height expansion (\%) of developed pork patties were measured by using digital vernier caliper at three different places and average value has been taken (Verma et al., 2015).

Decrease in diameter $(\%)=[$ (uncooked pork patty diameter - cooked pork patty diameter) / uncooked pork patty diameter] $\times 100$

Increase in height $(\%)=[($ cooked pork patty heightuncooked pork patty height) / uncooked pork patty height] $\times 100$ 


\section{Instrumental colour profile}

The instrumental colour profile of developed pork patties was determined by the Chroma Meter (CR-400 Konica Minolta, Osaka, Japan). The values of $L^{*}$ (lightness), $a^{*}$ (redness) and $b^{*}$ (yellowness) value of samples were determined by using with D65 illuminant, aperture size of $8 \mathrm{~mm}$ and standard observed of $2^{\circ}$. The equipment was calibrated with the white tiles provided with the equipment.

The Hue and chroma were calculated by using following formulas-

$$
\begin{gathered}
\text { Hue }\left(\mathrm{Hab}^{\circ}\right)=\left(\tan ^{-1}\right) \mathrm{b}^{*} / \mathrm{a}^{*} \\
\text { Chroma value }\left(\mathrm{Cab}^{\circ}\right)=\left(\mathrm{a}^{* 2}+\mathrm{b}^{* 2}\right)^{1 / 2}
\end{gathered}
$$

\section{Texture profile analysis}

Texture profile analysis of pork patties were measured by using a Texture Analyser (TMS-PRO, Food Technology Corporation, Maries Road, Suite 120 Sterling, VA, USA) and hardness, springiness, stringiness, cohesiveness, chewiness, gumminess and resilience were recorded using software (TMS-Pro, USA). The developed product was cut into uniform cube size of $1.0 \mathrm{~cm}^{3}$.

\section{Sensory evaluation}

Apanel of seven experienced members ( 4 male and 3 female) of faculty and postgraduate scholars of the department evaluated pork patties samples for appearance and colour, flavour, juiciness, tenderness and overall acceptability on 9-point descriptive scale, where $9=$ extremely like and $1=$ extremely unlike. Protocols for sensory analysis were approved by the Departmental Research Committee. Panelists were selected on the basis of their experience, availability and willingness. Samples were warmed (40$45^{\circ} \mathrm{C}$ ) using a microwave oven (LG Electronics India (P) Ltd., Mumbai) for $1.5 \mathrm{~min}$ before serving to panelist in sensory laboratory of the Department. The samples were blind-coded by using 3-digit numbers and presented to the panelists in random order on white colour glass plates. All sensory evaluations were conducted between 3.30 and $4.00 \mathrm{pm}$ and potable RO (reverse osmosis) filtered water was provided for rinsing the mouth in between samples.

\section{Statistical analysis}

Data obtained during various experiments were analyzed on SPSS-20.0 software packages, IBM Corporation, USA for Analysis of Variance (ANOVA) and Duncan's Multiple Range Test (DMRT) to compare the means. The whole set of experiment was replicated six times $(n=6)$ for the consistency of the results. Mean values were presented along with standard error. The statistical significance was estimated at $5 \%$ level $(\mathrm{P}<0.05)$.

\section{RESULTS AND DISCUSSION}

\section{Analysis of PHP and ATBP used in the study}

The peanut hull and arjuna tree bark powders are rich source of minerals and crude fibres but low in protein content (Table 3). The crude fibre content in ATBP was recorded $57.39 \%$ whereas in PHP, it was recorded $16.25 \%$. Both powders viz. PHP and ATBP were recorded with slight acidic value with ATBP exhibited lower $\mathrm{pH}$ than PHP. The protein content of PHP was recorded higher than ATBP. Similar high mineral content was also reported by Amalraj and Gopi (2017) in ATBP and Zhao et al. (2012) in peanut hull powder.

Table 3: Quality attributes of PHP and ATBP $($ Mean \pm SE)

\begin{tabular}{lll}
\hline Attributes & PHP & ATBP \\
\hline $\mathrm{pH}$ & $6.04 \pm 0.07$ & $5.63 \pm 0.05$ \\
Moisture (\%) & $9.89 \pm 0.52$ & $11.33 \pm 0.85$ \\
Protein (\%) & $6.69 \pm 0.75$ & $3.47 \pm 0.65$ \\
Crude Fibre (\%) & $16.25 \pm 0.81$ & $57.39 \pm 1.23$ \\
Ash (\%) & $2.84 \pm 0.25$ & $24.88 \pm 0.34$ \\
\hline
\end{tabular}

*PHP- peanut hull powder, ABTS- Arjuna tree bark powder.

\section{Physico-chemical and proximate parameters}

The various physico-chemical as well as proximate parameters of developed pork meat patties incorporated with various levels of PHP and ATBP are presented in Table 4. Among the $\mathrm{pH}$ of raw products, mean $\mathrm{pH}$ value of Control, T2 and T4 were comparable, whereas T4 recorded with comparable $\mathrm{pH}$ value with $\mathrm{T} 3$. The $\mathrm{T} 1$ samples recorded significantly $(\mathrm{P}<0.05)$ higher $\mathrm{pH}$ value than $\mathrm{T}$. On cooking, the $\mathrm{pH}$ value was recorded an increasing 
Table 4: Physico-chemical, proximate analysis of pork nuggets with PHP and ATBP(Mean \pm S.E.)*.

\begin{tabular}{llllll}
\hline Parameters & Control & T1 & T2 & T3 & T4 \\
\hline Emulsion parameters & & & & $6.27 \pm 0.02^{\mathrm{ab}}$ \\
\hline $\mathrm{pH}$ & $6.24 \pm 0.01^{\mathrm{a}}$ & $6.32 \pm 0.01^{\mathrm{c}}$ & $6.23 \pm 0.02^{\mathrm{a}}$ & $6.30 \pm 0.02^{\mathrm{b}}$ & $63.09 \pm 0.23$ \\
Moisture & $65.25 \pm 0.29$ & $64.76 \pm 0.30$ & $64.06 \pm 0.23$ & $63.32 \pm 0.25$ & $94.53 \pm 0.26^{\mathrm{d}}$ \\
Emulsion stability (\%) & $88.19 \pm 0.30^{\mathrm{a}}$ & $91.13 \pm 0.44^{\mathrm{b}}$ & $92.83 \pm 0.26^{\mathrm{c}}$ & $94.20 \pm 0.29^{\mathrm{d}}$ & \\
\hline Cooked product & & & & $6.32 \pm 0.01^{\mathrm{b}}$ \\
\hline $\mathrm{PH}$ & $6.35 \pm 0.02^{\mathrm{b}}$ & $6.33 \pm 0.01^{\mathrm{b}}$ & $6.28 \pm 0.01^{\mathrm{a}}$ & $6.35 \pm 0.01^{\mathrm{b}}$ & $84.34 \pm 0.42^{\mathrm{c}}$ \\
Cooking yield (\%) & $80.80 \pm 0.30^{\mathrm{a}}$ & $81.27 \pm 0.43^{\mathrm{a}}$ & $82.67 \pm 0.33^{\mathrm{b}}$ & $83.86 \pm 0.37^{\mathrm{c}}$ & $15.66 \pm 0.42^{\mathrm{a}}$ \\
Cooking loss (\%) & $19.20 \pm 0.30^{\mathrm{c}}$ & $18.73 \pm 0.43^{\mathrm{c}}$ & $17.33 \pm 0.33^{\mathrm{b}}$ & $16.15 \pm 0.37^{\mathrm{a}}$ & $57.08 \pm 0.15^{\mathrm{a}}$ \\
Moisture (\%) & $61.84 \pm 0.23^{\mathrm{d}}$ & $60.33 \pm 0.29^{\mathrm{c}}$ & $58.91 \pm 0.50^{\mathrm{b}}$ & $58.27 \pm 0.18^{\mathrm{b}}$ & $9.30 \pm 0.14^{\mathrm{a}}$ \\
Fat (\%) & $12.21 \pm 0.24^{\mathrm{c}}$ & $10.87 \pm 0.19^{\mathrm{b}}$ & $10.48 \pm 0.20^{\mathrm{b}}$ & $10.28 \pm 0.20^{\mathrm{b}}$ & $17.74 \pm 0.35^{\mathrm{a}}$ \\
Protein (\%) & $19.28 \pm 0.51^{\mathrm{b}}$ & $18.64 \pm 0.31^{\mathrm{ab}}$ & $18.51 \pm 0.33^{\mathrm{ab}}$ & $18.53 \pm 0.28^{\mathrm{ab}}$ & $2.89 \pm 0.06^{\mathrm{c}}$ \\
Ash (\%) & $2.01 \pm 0.04^{\mathrm{a}}$ & $2.37 \pm 0.03^{\mathrm{b}}$ & $2.80 \pm 0.03^{\mathrm{b}}$ & $2.43 \pm 0.02^{\mathrm{c}}$ & $1.15 \pm 0.18^{\mathrm{d}}$ \\
Crude fibre (\%) & $0.58 \pm 0.13^{\mathrm{a}}$ & $0.75 \pm 0.23^{\mathrm{ab}}$ & $0.98 \pm 0.21^{\mathrm{c}}$ & $0.85 \pm 0.15^{\mathrm{b}}$ & \\
\hline Dimensional parameters & & & & $36.44 \pm 0.49^{\mathrm{e}}$ \\
\hline Height Expansion (\%) & $21.49 \pm 0 .{ }^{6} 3 \mathrm{a}$ & $27.45 \pm 0.72^{\mathrm{b}}$ & $29.77 \pm 0.59^{\mathrm{c}}$ & $33.38 \pm 0.50^{\mathrm{d}}$ & $12.81 \pm 0.23^{\mathrm{c}}$ \\
\hline Diameter shrinkage (\%) & $10.51 \pm 0.35^{\mathrm{a}}$ & $11.36 \pm 0.35^{\mathrm{b}}$ & $12.51 \pm 0.36^{\mathrm{c}}$ & $13.01 \pm 0.35^{\mathrm{c}}$ & \\
\hline
\end{tabular}

*Means with different superscripts differ significantly $(\mathrm{P}<0.05)$ in a row; $\mathrm{n}=6$ for each treatment, PHP-peanut hull powder, ATBP-arjuna tree bark powder, T1 - pork patties with $0.5 \%$ PHP and $1.0 \%$ ATBP, T2 - pork patties with $0.5 \%$ PHP and $1.5 \%$ ATBP, T3 - pork patties with 1.0 $\%$ PHP and 1.0\% ATBP, T4- pork patties with $1.0 \%$ PHP and 1.5\% ATBP.

trend with their respective raw products. The $\mathrm{pH}$ of cooked products was recorded higher than their respective raw products. This increased $\mathrm{pH}$ on cooking could be due to higher degree of protein denaturation and production of imidazolium. Kumar et al. (2018a, b) reported similar increase in $\mathrm{pH}$ of pork patties upon cooking. The lower $\mathrm{pH}$ of $\mathrm{T} 2$ and $\mathrm{T} 4$ samples could be attributed to the higher content of incorporation of ATBP which exhibited lower $\mathrm{pH}$ value (5.63).

Addition of PHP and ATBP resulted in decreasing the moisture content in treated raw and cooked products. The moisture of raw control and treated products was recorded comparable. Among cooked patties, moisture content of $\mathrm{T} 4$ was recorded lowest and moisture content of $\mathrm{T} 3$ and $\mathrm{T} 4$ was recorded comparable. The moisture content of Control was recorded significantly $(\mathrm{P}<0.05)$ higher than $\mathrm{T} 1$. The lower moisture content in treated products could be lower due to incorporation of PHP and ATBP powders having low moisture content by replacing lean meat containing high moisture content.

Emulsion stability increased significantly $(\mathrm{P}<0.05)$ with the incorporation of PHP and ATBP levels in the product. The T3 and T4 samples reported the highest emulsion stability whereas $\mathrm{T} 1$ and $\mathrm{T} 2$ samples exhibited comparable $(\mathrm{P}>0.05)$ values. Higher emulsion stability resulted in increased cooking yield and decreased cooking loss of treated samples as compared to control. The cooking yield increased and the cooking loss decreased with the incorporation of PHP and ATBP in the products. The mean value of cooking yield and cooking loss of control and T1 as well as T3 and T4 were recorded comparable. This could be attributed to incorporation of PHP and ATBP powders containing high amount of dietary fibre resulting in stable emulsion and improved water holding capability. Verma et al. (2015a) also noticed similar results in pork patties incorporated with sweet potato powder and attributed it to the formation of stable protein-starch solid lattice structure, preventing the water and fat loss from cooked patties during cooking. Similar increase in emulsion stability and cooking yield value in meat products by incorporating vegetable powders having high fibre content was reported by Kumar et al. (2015) in chevon patties upon incorporation of finger millet flour, Singh et al. (2015 a; b) in meat cutlets upon incorporation of carrot and broccoli powder in meat cutlets, Kumar et al. (2013) in emu nuggets incorporated with broccoli powder, 
Goswami et al. (2017) in spent hen nuggets added with gooseberry pulp and seed coat powder, etc.

With increasing levels of PHP and ATBP in the developed products, mean fat and protein values exhibited decreasing trend whereas ash content showed increasing trend. The fat content of control was recorded highest and T4 showed lowest fat values. The fat content of all treated samples except T4 were comparable. The lowest protein content was recorded for T4 and control showed highest protein values. The protein content of all treated samples was recorded comparable. The ash content increased significantly $(\mathrm{P}<0.05)$ upon incorporation of PHP and ATBP as compared to control. The lower fat and protein contents and higher ash content of treated patties as compared to control could be due to incorporation PHP and ATBP which had low fat, protein and higher ash replacing lean meat in the treated products. Incorporation of PHP and ATBP powders in treated samples resulted in increased crude fibre content of these samples. Control exhibited significantly $(\mathrm{P}<0.05)$ lower crude fibre content treated patties. Among treated patties, T2 and T4 recorded higher crude fibre content due to high quantity of powder. This could be due to incorporation PHP and ATBP in treated patties which had higher fibre content replacing lean meat in the treated products.

Various dimensional parameters viz. height expansion (\%) and diameter shrinkage $(\%)$ were better retained in the PHP and ATBP incorporated patties than control patties. The better retained dimensional parameters in treated patties could be due to higher cooking yield and emulsion stability of these products attributed to inherent stabilizing and binding properties of PHP and ATBP containing high fibre content. However, at higher level of incorporation of PHP (1\%) and ATBP (1.5\%) incorporation in T4 sample resulted in significantly $(\mathrm{P}<0.05)$ higher height expansion and diameter shrinkage resulted in excessive swelling of the T4 patties. Similar findings have also been reported by Kumar et al. (2015) also reported similar findings in chevon patties incorporated with finger millet flours.

\section{Instrumental colour profiles}

The use of PHP and ATBP in patties has markedly affected various colour attributes (Fig. 1). The $L^{*}$ value of T2 and T3 was recorded comparable and significantly $(\mathrm{P}<0.05)$ higher than T4. Control sample exhibited significantly
$(\mathrm{P}<0.05)$ higher lightness value than $\mathrm{T} 1$ samples. The lower colour and appearance score of treated samples obtained during sensory assessment could be linked to the lower lightness score. This might be attributed to a non-enzymatic browning reaction (Maillard reaction) that occurs during cooking between PHP, ATBP, and meat proteins. Furthermore, the surface temperature of the patties remained below $100^{\circ} \mathrm{C}$ during preparation, which is a desirable temperature for the Maillard reaction. This could contribute to the appearance of natural colour of flavonoids in cooked treated pork patties. The $a^{*}$ value of control and treated patties was exhibited comparable value except T4 which exhibited significantly $(\mathrm{P}<0.05)$ lower $a^{*}$ value than all other samples. This may be attributed to elevated amounts of total phenolics, flavonoids, and pigments in PHP and ATBP, which resulted in a dark colour appearance on cooking. PHP and ATBP's natural green colour increased greenness while decreasing redness in treated patties. Yellowness $\left(b^{*}\right.$ values $)$ decreased significantly $(\mathrm{P}<0.05)$ in treatments as compared to control, and lowest yellowness value was recorded for T4. Similar findings have been documented by Verma et al. $(2015 \mathrm{a}, \mathrm{b})$ in pork patties. Hue angle $\left(\mathrm{Hab}^{\circ}\right)$, measurement of saturation of light, increased marginally and remained comparable between control and treatments. Chroma value $\left(\mathrm{Cab}^{*}\right)$ mathematically derived from $b^{*}$ and $a^{*}$ values decreased significantly $(\mathrm{P}<0.05)$ upon increasing levels of PHP and ATBP.

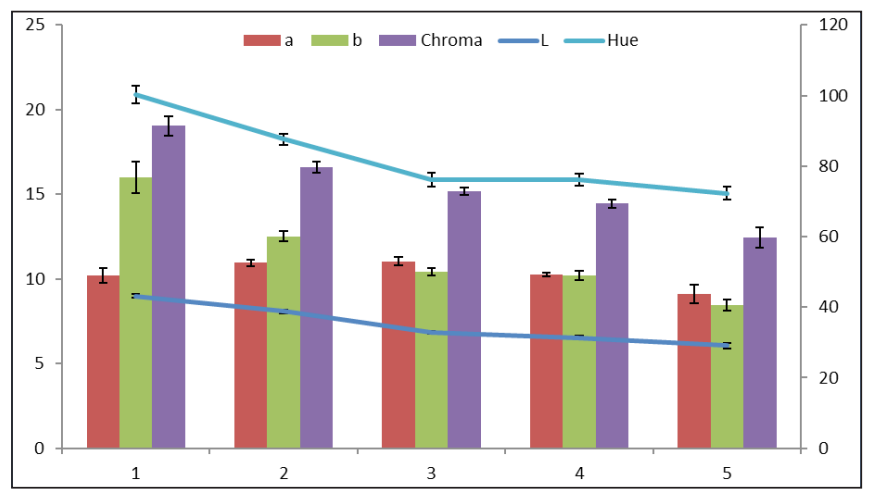

PHP- peanut hull powder, ATBP-arjuna tree bark powder, $\mathrm{n}=6$ for each treatment, T1 -pork patties with $0.5 \%$ PHP and $1.0 \%$ ATBP, T2 - pork patties with $0.5 \%$ PHP and $1.5 \%$ ATBP, T3 - pork patties with $1.0 \%$ PHP and $1.0 \%$ ATBP, T4- pork patties with $1.0 \%$ PHP and $1.5 \%$ ATBP

Fig. 1: Instrumental colour profile of pork patties incorporated with PHP and ATBS 


\section{Texture profile analysis}

The incorporation of PHP and ATBP into pork meat patties resulted in increasing in hardness value and decreasing springiness value (Table 5). The hardness value of control patties was recorded significantly $(\mathrm{P}<0.05)$ lower than $\mathrm{T} 1$. When higher amounts of PHP and ATBP were added to patties, the hardness value of the patties increased significantly $(\mathrm{P}<0.05)$, with $\mathrm{T} 4$ having the highest hardness values. This could be attributed to the formation of a high-quality gel matrix and improved water binding properties of treated products containing PHP and ATBP rich in fibre content. Kumar et al. (2018a) also reported similar decrease in hardness of pork patties incorporated with sapota powder and Kumar et al. (2015) in chevon patties incorporated with finger millet flour. The mean springiness value of control and T2 was recorded comparable and significantly $(\mathrm{P}<0.05)$ lower than $\mathrm{T} 1$. The chewiness value of T1, T2 and T3, T4 were comparable with each other. The change in springiness and chewiness value might be attributed to the inclusion of more soluble fibre in PHP and ATBP, which forms a gel-like texture and improved the elasticity of the handled patties, enhancing the amount of work required to masticate the sample. In control and treatment patties, the value of cohesiveness did not vary substantially $(\mathrm{P}>0.05)$. With the addition of PHP and ATBP, the value of gumminess decreased $(\mathrm{P}<0.05)$, as determined by hardness and cohesiveness. The disintegration of the sample during swallowing needed less force in treated patties.

\section{Sensory attributes}

PHP and ATBP incorporation was noticed to affect sensory attributes of pork meat patties (Table 5). All the sensory attributes viz. appearance and colour, flavour, juiciness, tenderness and overall acceptability showed decreasing

Table 5: Sensory evaluation and instrumental colour profile of goat meat biscuits incorporated with peanut hull powder (Mean \pm S.E.)*

\begin{tabular}{|c|c|c|c|c|c|}
\hline Parameters & Control & $\mathbf{T 1}$ & $\mathbf{T 2}$ & T3 & T4 \\
\hline \multicolumn{6}{|l|}{ Sensory evaluation } \\
\hline Appearance and colour & $8.55 \pm 0.06^{\mathrm{e}}$ & $8.11 \pm 0.03^{\mathrm{d}}$ & $7.93 \pm 0.03^{\mathrm{c}}$ & $7.52 \pm 0.04^{b}$ & $6.97 \pm 0.05^{\mathrm{a}}$ \\
\hline Flavour & $8.49 \pm 0.05^{\mathrm{d}}$ & $8.07 \pm 0.03^{c}$ & $8.02 \pm 0.03^{\mathrm{c}}$ & $7.39 \pm 0.06^{\mathrm{b}}$ & $6.74 \pm 0.04^{\mathrm{a}}$ \\
\hline Juiciness & $8.51 \pm 0.06^{\mathrm{e}}$ & $8.19 \pm 0.03^{\mathrm{d}}$ & $7.94 \pm 0.02^{\mathrm{c}}$ & $7.63 \pm 0.07^{\mathrm{b}}$ & $6.81 \pm 0.06^{\mathrm{a}}$ \\
\hline Tenderness & $8.50 \pm 0.04^{\mathrm{d}}$ & $8.25 \pm 0.03^{c}$ & $8.18 \pm 0.03^{c}$ & $7.41 \pm 0.05^{b}$ & $6.73 \pm 0.06^{\mathrm{a}}$ \\
\hline Overall acceptability & $8.54 \pm 0.06^{\mathrm{d}}$ & $8.10 \pm 0.02^{\mathrm{c}}$ & $8.05 \pm 0.02^{\mathrm{c}}$ & $7.35 \pm 0.06^{\mathrm{b}}$ & $6.73 \pm 0.05^{\mathrm{a}}$ \\
\hline \multicolumn{6}{|c|}{ Instrumental colour profile } \\
\hline $\mathrm{L}^{*}$ & $43.09 \pm 0.52^{\mathrm{d}}$ & $38.74 \pm 0.43^{c}$ & $32.79 \pm 0.40^{\mathrm{b}}$ & $31.28 \pm 0.52^{\mathrm{b}}$ & $29.05 \pm 0.81^{\mathrm{a}}$ \\
\hline$a^{*}$ & $10.19 \pm 0.44^{\mathrm{b}}$ & $10.94 \pm 0.21^{b}$ & $11.04 \pm 0.24^{\mathrm{b}}$ & $10.24 \pm 0.10^{\mathrm{b}}$ & $9.09 \pm 0.55^{\mathrm{a}}$ \\
\hline$b^{*}$ & $15.97 \pm 0.93^{\mathrm{d}}$ & $12.51 \pm 0.30^{\mathrm{c}}$ & $10.43 \pm 0.22^{b}$ & $10.21 \pm 0.29^{b}$ & $8.45 \pm 0.32^{\mathrm{a}}$ \\
\hline Chroma & $19.04 \pm 0.59^{d}$ & $16.62 \pm 0.33^{c}$ & $15.19 \pm 0.22^{b}$ & $14.46 \pm 0.25^{\mathrm{b}}$ & $12.43 \pm 0.61^{\mathrm{a}}$ \\
\hline Hue & $57.10 \pm 2.50^{\mathrm{c}}$ & $48.81 \pm 0.56^{\mathrm{b}}$ & $43.38 \pm 0.90^{\mathrm{a}}$ & $44.86 \pm 0.73^{\mathrm{a}}$ & $43.21 \pm 0.77^{\mathrm{a}}$ \\
\hline \multicolumn{6}{|l|}{ Texture Profile analysis } \\
\hline Hardness $\left(\mathrm{N} / \mathrm{cm}^{2}\right)$ & $12.92 \pm 0.44^{\mathrm{b}}$ & $10.80 \pm 0.28^{\mathrm{a}}$ & $14.51 \pm 0.58^{c}$ & $17.56 \pm 0.35^{\mathrm{d}}$ & $19.94 \pm 0.45^{\mathrm{e}}$ \\
\hline Springiness (cm) & $24.74 \pm 0.33^{\mathrm{d}}$ & $19.47 \pm 0.27^{\mathrm{c}}$ & $23.04 \pm 1.08^{\mathrm{d}}$ & $13.48 \pm 0.68^{b}$ & $10.26 \pm 0.28^{\mathrm{a}}$ \\
\hline Stringiness (mm) & $18.38 \pm 0.60^{\mathrm{ab}}$ & $19.89 \pm 0.65^{\mathrm{ab}}$ & $18.08 \pm 0.29^{\mathrm{a}}$ & $17.94 \pm 0.44^{\mathrm{a}}$ & $19.15 \pm 0.29^{b}$ \\
\hline Cohesiveness (ratio) & $0.61 \pm 0.02^{\mathrm{bc}}$ & $0.54 \pm 0.01^{\mathrm{ab}}$ & $0.52 \pm 0.01^{\mathrm{a}}$ & $0.59 \pm 0.01^{\mathrm{abc}}$ & $0.64 \pm 0.05^{\mathrm{c}}$ \\
\hline Chewiness (N/cm) & $186.09 \pm 3.12^{\mathrm{c}}$ & $164.68 \pm 5.36^{\mathrm{b}}$ & $174.12 \pm 5.00^{\mathrm{b}}$ & $97.99 \pm 1.50^{\mathrm{a}}$ & $99.64 \pm 3.37^{\mathrm{a}}$ \\
\hline Gumminess $\left(\mathrm{N} / \mathrm{cm}^{2}\right)$ & $7.96 \pm 0.28^{\mathrm{ab}}$ & $7.10 \pm 0.08^{a}$ & $7.78 \pm 0.14^{\mathrm{ab}}$ & $8.76 \pm 0.38^{\mathrm{b}}$ & $8.54 \pm 0.59^{b}$ \\
\hline Resilience (ratio) & $2.36 \pm 0.14$ & $2.33 \pm 0.07$ & $2.46 \pm 0.12$ & $2.61 \pm 0.24$ & $2.35 \pm 0.08$ \\
\hline
\end{tabular}

*Means with different superscripts differ significantly $(\mathrm{P}<0.05)$ in a row; $\mathrm{n}=6$ for each treatment, PHP-peanut hull powder, ATBP-arjuna tree bark powder, T1 - pork patties with $0.5 \%$ PHP and 1.0\% ATBP, T2 - pork patties with $0.5 \%$ PHP and $1.5 \%$ ATBP, T3 - pork patties with 1.0 $\%$ PHP and 1.0\% ATBP, T4- pork patties with $1.0 \%$ PHP and $1.5 \%$ ATBP. 
trends with the incorporation of PHP and ATBP. The appearance score of control $\mathrm{T} 1$ and $\mathrm{T} 2$ were recorded comparable and were significantly higher $(\mathrm{P}<0.05)$ than $\mathrm{T} 3$ and $\mathrm{T} 4$.

With higher levels of PHP and ATBP incorporation, all sensory attributes, such as appearance and colour, flavour, juiciness, texture and overall acceptability, showed decreasing patterns. The appearance and colour score of Control was recorded significantly $(\mathrm{P}<0.05)$ higher than T1. This may be attributed to the incorporation of PHP and ATBS powders resulting in a lower lightness $\left(\mathrm{L}^{*}\right)$ in the instrumental colour profile. The mean flavour score of the T1 and T2 samples was recorded comparable and significantly higher than other treated products viz. T3 and T4. This may be attributed to the production of volatile compounds and their regulated release in the treated patties due to incorporation of PHP and ATBP resulting in lower flavour score. The T4 samples had the lowest flavour scores due to incorporation of highest levels of PHP and ATBP. The mean juiciness score of T2 was recorded significantly $(\mathrm{P}<0.05)$ lower than $\mathrm{T} 1$, which intern exhibited significantly $(\mathrm{P}<0.05)$ lower value than control. The tenderness score of $\mathrm{T} 1$ and $\mathrm{T} 2$ was recorded comparable. The mean overall acceptability score of $\mathrm{T} 2$ was comparable to T1. The overall acceptability of control was recorded significantly $(\mathrm{P}<0.05)$ higher than $\mathrm{T} 1$ and $\mathrm{T} 2$. The presence of higher concentration of tannins, polyphenols and flavonoids in PHP and ATBP resulted in decreased $(\mathrm{P}<0.05)$ overall acceptability of treated samples as compared to control. The overall acceptability further decreased $(\mathrm{P}<0.05)$ in $\mathrm{T} 3$ and $\mathrm{T} 4$ samples, might be due to higher incorporations of PHP and ATBP concentrations. The inclusion of PHP resulted in cognize bitterness by the sensory semi trained panelist and this bitterness was very pronounced in T3 and T4, contributing to lower overall acceptability score during sensory evaluation. The overall acceptability of T2 samples viz. $0.5 \%$ PHP and $1.5 \%$ ATBP was recorded 8.05 and it falls under the category of 'very much acceptable'.

\section{CONCLUSION}

It can be concluded that low fat, high fibre, functional pork patties with good organoleptic quality can be prepared by incorporation of $0.5 \%$ peanut hull powder and $1.5 \%$ arjuna tree bark powder.

\section{REFERENCES}

Akgul, M. and Tozluoglu, A. 2008. Utilizing peanut husk (Arachis hypogaea L.) in the manufacture of medium-density fiberboards. Bioresour. Technol., 99: 5590-5594.

Amalraj, A. and Gopi, S. 2017. Medicinal properties of Terminalia arjuna (Roxb.): a review. J. Tradit. Complem. Med., 7: 65-78.

AOAC. 2006. Official methods of analysis Method 992.15. Proximate Analysis and Calculations Crude Protein Meat and Meat Products Including Pet Foods. 17 th ed. Gaithersburg: Association of Analytical Communities.

Birla, R., Malav, O.P., Wagh, R.V., Mehta, N. and Chatli, M.K. 2019. Storage stability of pork emulsion incorporated with Arjuna (Terminalia arjuna) tree bark extract. Int. J. Livest. Res., 9(2): 95-109.

Bishnoi, S., Ahlawat, S.S., Bishnoi, N., Kumar, S. and Jain, S. 2017. Effect of aloe vera gel and arjun tree bark extract incorporation on quality of buffalo male calf meat rolls during refrigeration $\left(4 \pm 1^{\circ} \mathrm{C}\right)$ storage. J. Anim. Res., 7(1): 69-75.

Goswami, M.M., Prajapati, B.I., Nalwaya, S.B., Solanki, B.A., Deokar, S.S. and Solanki, T.H. 2017. Effect of gooseberry pulp and gooseberry seed coat powder (Emblica officinalis) on some quality and sensory attributes of chicken nuggets. Trends Biosci., 10(28): 6063-6069.

Kantale, R.A., Kumar, P., Mehta, N., Chatli, M.K., Malav, O.P., Kaur, A. and Wagh, R.V. 2019. Comparative efficacy of synthetic and natural tenderizers on quality characteristics of restructured spent hen meat slices (RSHS). Food Sci. Anim. Resour., 39(1): 121-128.

Kumar, D., Chatli, M.K., Mehta, N., Verma, A.K. and Kumar, P. 2015. Quality evaluation of chevon patties fortified with dietary fibre. Indian J. Small Rumin., 21(1): 85-91.

Kumar, P., Chatli, M.K., Mehta, N., Malav, O.P., Verma, A.K., Kumar, D. and Rathour, M. 2018a. Antioxidant and antimicrobial efficacy of sapota powder in pork patties stored under different packaging conditions. Korean J. Food Sci. Anim. Resour., 38(3): 593-605.

Kumar, P., Kumar, S., Tripathi, M. K., Mehta, N., Ranjan, R., Bhat, Z.F. and Singh, P.K. 2013. Flavonoids in the development of functional meat products: A review. Vet. World, 6: 573-578

Kumar, P., Mehta, N., Malav, O. P., Kumar Chatli, M., Rathour, M., and Verma, A.K. 2018b. Antioxidant and antimicrobial efficacy of watermelon rind extract (WMRE) in aerobically packaged pork patties stored under refrigeration temperature $\left(4 \pm 1^{\circ} \mathrm{C}\right)$. J. Food Process. Preserv., 42(10): 1-12.

Mayank M, Roy, S.K., Prajapati, B.I., Deokar, S.S., Nalwaya, S.B. and Solanki, B.A. 2020. Effect of gooseberry pulp and 
seed coat powder as natural preservatives on the storage quality of chicken nuggets. J. Anim. Res., 10(4): 601-607.

Singh, P.K., Kumar, S., Bhat, Z.F., Kumar, P. and Kumar, A. 2015b. Effect of processed oats and clove oil on the characteristics and storage quality of aerobically packaged chevon cutlets. Indian J. Small Rumin., 21(1): 76-84.

Singh, P.K., Kumar, S., Kumar, P. and Bhat, Z.F. 2014a. Effect of mincing on the quality characteristics of chevon cutlets. $J$. Anim. Res., 4(2): 193-200.

Singh, P.K., Kumar, S., Bhat, Z.F. and Kumar, P., 2014b. Effect of clove oil on the storage quality of aerobically packaged fiber-enriched chevon cutlets. J. Meat Sci., 10(1): 36-43.

Singh, T., Chatli, M.K., Kumar, P., Mehta, N. and Malav, O.P. 2015a. Comparative efficacy of different binders in the development of chicken meat cutlets. J. Anim. Res., 5: 455459.

Singh, T., Chatli, M.K., Kumar, P., Mehta, N. and Malav, O.P. 2015b. Effect of carrot powder on the quality attributes of fibre-enriched spent hen meat cutlets. J. Anim. Res., 5: 737742.
Verma, A.K., Chatli, M.K., Kumar, D., Kumar, P. and Mehta, N. 2015a. Efficacy of sweet potato powder and added water as fat replacer on the quality attributes of low-fat pork patties. Asian-australas. J. Anim. Sci., 28(2): 252-259.

Verma, A.K., Chatli, M.K., Mehta, N. and Kumar, P., 2015b. Process protocol and cost of production of functional fiberenriched pork loaves. J. Anim. Res., 5(1): 135-142.

WHO/FAO. 2003. Diet, nutrition and prevention of chronic diseases. WHO technical report series 916, Geneva, Switzerland.

Yu, L., Gong, Q., Yang, Q., Sun, J., Bi, J. and Zhang, C. 2011. Technology optimization for microwave-assisted extraction of water soluble dietary fiber from peanut hull and its antioxidant activity. Food Sci. Technol. Res., 17: 401-8.

Zhao, X., Chen, J. and Du, F. 2012. Potential use of peanut by-products in food processing: a review. J. Food Sci. Technol., 49(5): 521-529. 
